PIWULANG: Jurnal Pendidikan Agama Islam, Vol. 3 No. 2 Maret 2021, 143-156

P-ISSN : 2622-5638. E-ISSN : 2622-5654

Homepage: http://e-journal.staima-alhikam.ac.id/index.php/piwulang

\title{
PENGARUH PENERAPAN STRATEGI PEMBELAJARAN KOOPERATIF TIPE TEAMS GAMES TOURNAMENT (TGT) TERHADAP HASIL BELAJAR SISWA DALAM MATA PELAJARAN FIQIH DI MTS NEGERI PUTUSSIBAU
}

\author{
Hardimansyah \\ STIT Iqra' Kapuas Hulu - Indonesia \\ Email: hardimansyah@stitiqra.ac.id
}

\begin{abstract}
This study aims to determine whether the team games tournament type cooperative learning strategy is effective for improving student learning outcomes at MTs Negeri Putussibau by using the cluster random sampling method, the VIIIA class is the experimental class and the VIIIB class is the control class and the VIIIC class is the trial class. This research is an experimental research. The collection technique used a questionnaire, observation methods and test methods. From the analysis, it was obtained that the experimental class average was obtained 65.88 with Standard Deviation (SD) $=11.51$ and the control class average was obtained 58.82 with Standard Deviation $(S D)=9.05$ and then tested using the $t$ test. obtained $t$ count $=2.811$ and from the distribution table obtained table t table $=1.67$ with $\alpha=0.05$ and $d k=34+34-2=66$. This shows that $t$ count $>t$ table, so $H$ 1: ? 1> ? 2 tang means that the cooperative learning model of the Team Games Tournament type is more effective in improving student learning outcomes.
\end{abstract}

\begin{abstract}
Abstrak
Penelitian ini bertujuan untuk mengetahui apakah strategi pembelajaran kooperatif tipe teams games tournament efektif untuk meningkatkan hasil belajar peserta didik di MTs Negeri Putussibau dengan metode cluster random sampling, diperoleh kelas VIIIA sebagai kelas eksperimen dan kelas VIIIB sebagai kelas kontrol dan kelas VIIIC sebagai kelas uji coba. Penelitian ini merupakan penelitian eksperimen. Teknik pengumpulan dengan angket, metode observasi dan metode tes. Dari hasil analisis diperoleh rata-rata kelas eksperimen diperoleh 65,88 dengan Standar Deviasi (SD)=11,51 dan rata-rata kelas kontrol diperoleh 58,82 dengan Standar Deviasi (SD)=9,05 untuk selanjutnya diuji dengan menggunakan uji $t$ diperoleh $t_{\text {hitung }}=2,811$ dan dari tabel distribusi diperoleh tabel tabel $=1,67$ dengan $\alpha=0,05$ dan $\mathrm{dk}=34+34-$ $2=66$. Hal ini menunjuk kan bahwa thitung $>t$ tabel , jadi $H_{1}:$ 目 ${ }_{1}>$ ? 2 tang berarti pembelajaran model pembelajaran kooperatif tipe Team Games Tournament efektif lebih berpengaruh untuk meningkatkan hasil belajar peserta didik.
\end{abstract}

Kata kunci: Strategi Pembelajaran, Times Games Tournaments, Hasil Belajar. 
PIWULANG: Jurnal Pendidikan Agama Islam, Vol. 3 No. 2 Maret 2021, 143-156

P-ISSN : 2622-5638. E-ISSN : 2622-5654

Homepage: http://e-journal.staima-alhikam.ac.id/index.php/piwulang

\section{A. Pendahuluan}

Dalam upaya mencapai pendidikan yang berkualitas, pemerintah telah mengubah kurikulum berbasis kompetensi (KBK) menjadi kurikulum tingkat satuan pendidikan (KTSP). Kurikulum tingkat satuan pendidikan (KTSP) merupakan strategi pengembangan kurikulum untuk mewujudkan sekolah yang efektif. produktif dan berprestasi. Kurikulum tingkat satuan pendidikan (KTSP) dikembangkan sesuai dengan satuan pendidikan, potensi, karakteristik daerah, serta sosial budaya masyarakat setempat dari peserta didik. ${ }^{1}$

Kurikulum tingkat satuan pendidikan (KTSP) merupakan paradigma baru pengembangan kurikulum, yang memberikan otonomi luas pada setiap satuan pendidikan, dan pelibatan masyarakat dalam mengaktifkan proses belajar mengajar di sekolah. Dalam pelaksanaan kurikulum tingkat satuan pendidikan (KTSP) pendidik diharapkan dapat menciptakan suasana baru di dalam proses kegiatan belajar mengajar, agar peserta didik lebih mudah untuk menerima materi yang disampaikan.

Beberapa mata pelajaran Agama pun tidak luput dari revisi kurikulum. Mulai dari Aqidah Akhlak, Quran Hadits, Sejarah Kebudayaan Islam dan Fiqih. Mata pelajaran Fiqih dalam kurikulum Madrasah Tsanawiyah (MTs) adalah salah satu bagian mata pelajaran pendidikan Islam yang memberikan bimbingan kepada peserta didik agar dapat dijadikan dasar dalam pandangan hidupnya (way of life) dengan standar kompetensi yang ditetapkan yaitu kemampuan berorientasi pada prilaku efektif, psikomotorik dengan dukungan pengetahuan kognitif, tetapi banyak peserta didik yang hanya tahu dari segi kognitifnya saja dan tidak tahu bagaimana cara beribadah yang baik, yang mengakibatkan ibadahnya kurang efektif.

Dalam pembelajaran Fiqih yang mengacu pada kurikulum tingkat satuan pendidikan (KTSP), setiap standar kompetensi yang ada terdapat beberapa pemecahan masalah. Disamping itu juga dibutuhkan kreatifitas guru dalam menerapkan strategi pembelajaran yang mengacu pada prilaku dan proses berfikir. Penggunaan strategi pembelajaran harus menyesuaikan dengan materi yang akan dipelajari baik metode maupun model pembelajaran agar peserta didik mampu mencapai tujuan pembelajaran dengan maksimal. Berdasarkan hasil observasi awal dan wawancara peneliti dengan Guru MTs Negeri Putussibau, bahwa dalam

\footnotetext{
1 E. Mulyasa, Kurikulum Tingkat Satuan Pendidikan Sebuah Panduan Praktis, (Bandung:Remaja Rosdakarya, 2007), hlm. 20.
} 
PIWULANG: Jurnal Pendidikan Agama Islam, Vol. 3 No. 2 Maret 2021, 143-156

P-ISSN : 2622-5638. E-ISSN : 2622-5654

Homepage: http://e-journal.staima-alhikam.ac.id/index.php/piwulang

proses pembelajaran fiqih metode yang digunakan adalah lebih banyak menggunakan metode konvensional yaitu ceramah dan sebatas tanya jawab. Peserta didik hanya menelan dan mendengarkan hal-hal yang disampaikan oleh guru. Apalagi karakteristik anak didik khususnya kelas yang diteliti yaitu kelas VIII, kurang tertarik belajar fiqih.

Strategi yang digunakan jelas kurang tepat jika diterapkan dalam proses KBM tersebut. Akibatnya, hasil belajar peserta didik belum maksimal. Untuk mengatasi permasalahan tersebut peneliti merasa tertantang untuk mencari alternatif strategi pembelajaran yang melibatkan siswa secara keseluruhan dan dapat meningkatkan hasil belajar siswa dalam mata pelajaran fiqih. Strategi pembelajaran kooperatif (cooperative learning) yang dipadukan dengan permainan secara berkelompok. Dalam strategi pembelajaran kooperatif tipe teams games tournament (TGT) secara positif mengandung unsur model kompetisi yang dapat menimbulkan rasa cemas yang justru bias memotivasi siswa meningkatkan kegiatan belajar mereka. Sedikit rasa cemas memang mempunyai korelasi positif dengan motivasi belajar. Sehingga peserta didik menjadi lebih kritis dalam memecahkan masalah serta lebih leluasa dalam melakukan eksplorasi, yang akhirnya dapat meningkatkan hasil belajar peserta didik karena ada motivasi untuk bersaing.

Kegiatan pembelajaran Fiqih di MTs Negeri Putussibau harus memberikan kesempatan kepada peserta didik untuk melakukan kegiatan, dan guru hanya sebagai fasilitator. Artinya selama proses pembelajaran, guru berfungsi sebagai penyedia atau pembimbing untuk mempermudah kegiatan-kegiatan pembelajaran. Dengan begitu, materi Agama yang dipelajari peserta didik bukan sesuatu yang dituntut, tetapi sesuatu yang dicari, dipahami kemudian dilaksanakan dalam kehidupan sehari-hari.

Berangkat dari permasalahan tersebut penelitian ini hendak memfokuskan pada Seberapa jauh pengaruh penggunaan Strategi pengajaran tipe teams games tournament (TGT) terhadap hasil pembelajaran fiqih siswa di kelas VIII MTs Negeri Putussibau.

\section{B. Metode.}

Penelitian ini menggunakan metode kuantitatif. Metode penelitian kuantitatif ini menggunakan pendekatan eksperimen yang berdesain "posttest-only control, dengan tujuan untuk mencari pengaruh treatment. Sedangkan desain atau rancangan ini terdiri dari dua kelas yaitu: kelas eksperimen (kelas yang menggunakan strategi TGT) dan kelas kontrol sebagai kelas pembanding yaitu menggunakan metode ceramah. 
PIWULANG: Jurnal Pendidikan Agama Islam, Vol. 3 No. 2 Maret 2021, 143-156

P-ISSN : 2622-5638. E-ISSN : 2622-5654

Homepage: http://e-journal.staima-alhikam.ac.id/index.php/piwulang

Sampel yang diambil dalam penelitian ini adalah tiga kelas. Sampel diambil dengan teknik simple random sampling yaitu pengambilan anggota sampel dari populasi dilakukan secara acak tanpa memperhatikan strata yang ada dalam populasi. Pengambilan sampel dalam penelitian ini peneliti memperhatikan ciri-ciri antara lain peserta didik mendapatkan materi berdasarkan kurikulum yang sama dan pembagian kelas tidak ada kelas unggulan.

\section{Hasil dan Pembahasan}

Sebelum peneliti menentukan teknik analisis statistik yang digunakan, terlebih dahulu peneliti memeriksa keabsahan sampel. Cara yang digunakan untuk memeriksa keabsahan sampel tersebut adalah uji normalitas, uji homogenitas, dan uji kesamaan dua rata-rata. Uji normalitas ini digunakan untuk mengetahui data terdistribusi secara normal atau tidak, untuk mengetahui distribusi data yang diperoleh, dilakukan uji normalitas dengan uji Chi-Kuadrat. Uji homogenitas dilakukan untuk mengetahui apakah data tersebut homogen atau tidak. Pengujian homogen data dilakukan dengan uji Bartlett. Uji kesamaan dua rata-rata ini bertujuan untuk mengetahui apakah kelompok eksperimen dan kelompok kontrol mempunyai rata-rata nilai yang tidak berbeda pada tahap awal ini. Jika ratarata kedua kelompok tersebut berbeda berarti kelompok itu mempunyai kondisi yang sama. Uji beda dalam penelitian ini adalah menggunakan rumus $t$-test untuk menguji signifikansi perbedaan dua buah mean yang berasal dari dua buah distribusi.

\begin{tabular}{|l|l|l|l|l|l|}
\hline No & Kelas & Kemampuan & $\chi^{2}$ hitung & $\chi 2$ tabel & Keterangan \\
\hline 1 & Eksperimen & Post Test & 1.855 & 7.81 & Normal \\
\hline 2 & Kontrol & Post Test & 4.4678 & 7.81 & Normal \\
\hline
\end{tabular}

Tabel 1. Daftar Hasil Uji Normalitas

Tes Akhir Kelas Eksperimen Dan Kontrol 
PIWULANG: Jurnal Pendidikan Agama Islam, Vol. 3 No. 2 Maret 2021, 143-156

P-ISSN : 2622-5638. E-ISSN : 2622-5654

Homepage: http://e-journal.staima-alhikam.ac.id/index.php/piwulang

\begin{tabular}{|l|l|l|l|l|l|}
\hline No & \multicolumn{1}{|c|}{ Kelas } & \multicolumn{1}{|c|}{ hitung } & & tabel & Keterangan \\
\hline 1 & Eksperimen & 0.9072 & 11.1 & Homogen \\
\hline 2 & Kontrol & 6.6253 & 11.1 & Homogen \\
\hline
\end{tabular}

Tabel 2. Daftar Hasil Uji Homogenitas

Tes Akhir Kelas Eksperimen DanKontrol

\begin{tabular}{|c|c|c|}
\hline $\begin{array}{l}\text { Sumber } \\
\text { Variasi }\end{array}$ & $\begin{array}{c}\text { VIIIA } \\
\text { (Kelas Eksperimen) }\end{array}$ & $\begin{array}{c}\text { VIIIB } \\
\text { (Kelas Kontrol) }\end{array}$ \\
\hline Jumlah & 2240 & 2000 \\
\hline & 34 & 34 \\
\hline- & 65,88 & 58,82 \\
\hline Varians $\left(\mathrm{S}^{2}\right)$ & 132,531 & 81,907 \\
\hline Standart deviasi & 11,51 & 9,05 \\
\hline
\end{tabular}

Tabel. 3. Tabel Sumber Data

Untuk Uji Perbedaan Dua Rata-rata

\begin{tabular}{|l|l|l|}
\hline No & Aspek Pengamatan & Skor \\
\hline & Sikap saat mengikuti diskusi & 111 \\
\hline & Bekerjasama dalam kelompok & 103 \\
\hline & $\begin{array}{l}\text { Memberikan pendapat atau masukan } \\
\text { dalam diskusi }\end{array}$ & 100 \\
\hline & Menjelaskan hasil diskusi & 106 \\
\hline Jumlah & 420 \\
\hline Rata-rata & 12,35 \\
\hline
\end{tabular}

Tabel. 4. Tabel hasil observasi

pelaksanaan aktifitas belajar Peserta didik 
PIWULANG: Jurnal Pendidikan Agama Islam, Vol. 3 No. 2 Maret 2021, 143-156

P-ISSN : 2622-5638. E-ISSN : 2622-5654

Homepage: http://e-journal.staima-alhikam.ac.id/index.php/piwulang

\begin{tabular}{|c|l|c|}
\hline No & \multicolumn{1}{|c|}{ Aspek Pengamatan } & Skor \\
\hline 1 & Apersepsi & 13 \\
\hline 2 & Penyampaian materi pokok & 11 \\
\hline 3 & $\begin{array}{l}\text { Penerapan pembelajaran kooperatif tipe } \\
\text { Teams Games Tournament (TGT), }\end{array}$ & 17 \\
\hline 4 & Menutup pelajaran & 6 \\
\hline & Uumlah & 47 \\
\hline & Prosentase & $83,93 \%$ \\
\hline & Kategori & Baik Sekali \\
\hline
\end{tabular}

Tabel. 5. Hasil observasi

pengamatan pelaksanaan pembelajaran guru

\begin{tabular}{|c|c|c|c|}
\hline $\begin{array}{l}\text { Kriteria } \\
\text { Tanggapan }\end{array}$ & Skor & Jumlah & Presentase \\
\hline Rendah & $0-15$ & 0 & $00,00 \%$ \\
\hline Sedang & $16-31$ & 15 & $44,12 \%$ \\
\hline Tinggi & $32-48$ & 19 & $55,88 \%$ \\
\hline & Jumlah & 34 & $100 \%$ \\
\hline & Rata-rata & & $69,12 \%$ \\
\hline
\end{tabular}

Tabel. 6. Hasil angket tanggapan peserta didik terhadap strategi Teams Games Tournament (TGT)

Dari hasil penelitian dapat diketahui bahwa hasil belajar yang diperoleh peserta didik dengan strategi pembelajaran kooperatif tipe TGT (kelas eksperimen) mencapai rata-rata 65,88 dan Standar Deviasi (SD) = 11,51 sedangkan untuk hasil belajar yang diperoleh peserta didik dengan pembelajaran konvensional (kelas kontrol) mencapai rata-rata 58,82 dan Standar Deviasi (SD) $=9,05$. Berdasarkan hasil penelitian diperoleh ratarata peserta didik kelas eksperimen yang diajar dengan strategi pembelajaran kooperatif tipe TGT pada materi makanan dan minuman (kelas eksperimen) $X=65,88$ sedangkan nilai rata-rata peserta didik kelas kontrol $X=58,82$. Dengan demikian hasil belajar peserta didik yang diajar 
PIWULANG: Jurnal Pendidikan Agama Islam, Vol. 3 No. 2 Maret 2021, 143-156

P-ISSN : 2622-5638. E-ISSN : 2622-5654

Homepage: http://e-journal.staima-alhikam.ac.id/index.php/piwulang

dengan model pembelajaran kooperatif tipe TGT (kelas eksperimen) lebih baik dari hasil belajar peserta didik dengan menggunakan metode konvensional.

\section{Pembahasan}

\section{1) Konsep Hasil belajar}

Hasil belajar merupakan hasil proses belajar. Hasil belajar merupakan "tingkat perkembangan mental" yang lebih baik bila dibanding pada saat pra belajar. Jadi hasil belajar adalah suatu perolehan dari suatu proses dengan ditandai dengan perubahan. Menurut Abin Syamsudin Makmun pengertian hasil belajar adalah sebagai berikut: ${ }^{2}$

a. Pertambahan materi pengetahuan yang berupa fakta, informasi, prinsip atau hukum atau kaidah prosedur atau pola kerja atau teori sistem nilai-nilai dan sebagainya.

b. Penguasaan pola-pola prilaku kognitif (pengamatan) proses berfikir, mengingat atau mengenai kembali, perilaku afektif (sikapsikap apresiasi penghayatan, dan sebagainya), prilaku psikomotorik (keterampilan-keterampilan psikomotorik) termasuk yang bersifat ekspresi.

c. Perubahan dalam sifat-sifat yang baik.

Berdasarkan definisi diatas, dapat disimpulkan bahwa hasil belajar adalah hasil yang dicapai peserta didik dalam menuntut sesuatu pelajaran yang menunjukkan taraf kemampuan peserta didik dalam mengikuti program belajar dalam waktu tertentu sesuai dengan kurikulum yang telah ditentukan. Prestasi belajar ini sering dicerminkan sebagai nilai yang menentukan berhasil tidaknya peserta didik setelah belajar.

\section{2) Aspek-aspek hasil belajar}

a. Aspek hasil belajar bidang kognitif

Aspek hasil belajar bidang kognitif adalah ranah yang berkaitan dengan kegiatan mental. Menurut Bloom, segala upaya yang menyangkut aktivitas otak adalah ranah kognitif. Dalam ranah kognitif terdapat enam jenjang proses berpikir yaitu: ${ }^{3}$

1. Pengetahuan (knowledge) adalah kemampuan seseorang untuk mengingat-ingat kembali (recall) atau mengenali kembali tentang

2.Abin Syamudin Makmun, Psikologi Kependidikan, (Bandung: PT Remaja Rosdakarya, 2007), hlm. 160-161.

${ }^{3}$.Anas Sudijono, Pengantar Evaluasi Pendidikan (Jakarta: PT Raja Grafindo Persada, 2009), hlm. 49. 
PIWULANG: Jurnal Pendidikan Agama Islam, Vol. 3 No. 2 Maret 2021, 143-156

P-ISSN : 2622-5638. E-ISSN : 2622-5654

Homepage: http://e-journal.staima-alhikam.ac.id/index.php/piwulang

nama, istilah, ide, gejala, rumus-rumus dan sebagainya, tanpa mengharapkan kemampuan untuk menggunakannya.

2. Pemahaman (comprehension) adalah kemampuan seseorang untuk mengerti atau memahami sesuatu setelah sesuatu itu diketahui dan diingat. Peserta didik dikatakan memahami sesuatu apabila dapat memberikan penjelasan atau memberi uraian yang lebih rinci tentang hal itu dengan menggunakan kata-katanya sendiri.

3. Penerapan (application) adalah kesanggupan seseorang untuk menerapkan atau menggunakan ide-ide umum, tata cara ataupun metode-metode, prinsip-prinsip, rumus-rumus, teori-teori dan sebagainya dalam situasi yang baru dan kongkret.

4. Analisis (analysis) adalah kemampuan seseorang untuk merinci atau menguraikan suatu bahan atau keadaan menurut bagianbagian yang lebih kecil dan mampu memahami hubungan diantara bagian-bagian atau faktor-faktor yang satu dengan faktor-faktor yang lain.

5. Sintesis (synthesis) adalah kemampuan berpikir yang merupakan kebalikan dari berpikir analisis. sintesis merupakan suatu proses yang memadukan bagian-bagian atau unsure-unsur secara logis, sehingga menjelma menjadi suatu pola baru.

6. Evaluasi (evaluation) adalah kemampuan seseorang untuk membuat pertimbangan terhadap suatu situasi, nilai atau ide.

b. Aspek hasil belajar bidang afektif

Ranah afektif adalah ranah yang berkaitan dengan sikap dan nilai. Beberapa pakar mengatakan bahwa sikap seseorang dapat diramalkan perubahannya bila seseorang telah memiliki penguasaan kognitif tingkat tinggi. Aspek hasil belajar afektif tampak pada siswa dalam berbagai tingkah laku seperti atensi atau perhatian terhadap pelajaran, disiplin, motivasi belajar, menghargai guru dan teman sekelas, kebiasaan belajar, dan lain-lain.

Ada beberapa tingkatan aspek afektif sebagai tujuan dan aspek hasil belajar. Tingkatan tersebut dimulai dari tingkat yang dasar atau sederhana sampai tingkatan yang kompleks yaitu:

1. Receiving/attending, yakni semacam kepekaan dalam menerima rangsangan (stimulasi) dari luar yang datang pada siswa, baik dalam bentuk masalah, situasi, gejala dan lain-lain.

2. Responding atau menanggapi mengandung arti adanya partisipasi aktif. Jadi kemampuan menanggapi adalah kemampuan yang dimiliki oleh seseorang untuk mengikutsertakan dirinya secara aktif dalam fenomena tertentu. 
PIWULANG: Jurnal Pendidikan Agama Islam, Vol. 3 No. 2 Maret 2021, 143-156

P-ISSN : 2622-5638. E-ISSN : 2622-5654

Homepage: http://e-journal.staima-alhikam.ac.id/index.php/piwulang

3. Valuing (penilaian), yakni menilai atau menghargai artinya memberikan nilai atau memberikan penghargaan terhadap suatu kegiatan atau objek.

4. Organisasi, yakni mempertemukan perbedaan nilai sehingga terbentuk nilai baru yang lebih universal, yang membawa kepada perbaikan umum.

5. Karakteristik nilai atau internalisasi nilai yakni keterpaduan dari semua system nilai yang telah dimiliki seseorang, yang mempengaruhi pola kepribadian dan tingkah lakunya.

c. Aspek hasil belajar bidang psikomotor

Ranah psikomotor adalah ranah yang berkaitan dengan keterampilan (skill) atau kemampuan bertindak setelah seseorang menerima pengalaman belajar tertentu. Wujud nyata dari hasil belajar psikomotorik yang merupakan kelanjutan dari hasil belajar kognitif dan afektif adalah:

1. Peserta didik mencari dan membaca buku-buku, majalah, brosur, dan lain-lain

2. Peserta didik dapat memberikan penjelasan kepada teman-teman sekelasnya di sekolah

3. Peserta didik menganjurkan kepada teman-teman sekolah atau adik-adiknya agar berlaku disiplin

4. Peserta didik dapat memberikan contoh-contoh perilaku disiplin di sekolah

5. Peserta didik dapat memberikan contoh kedisiplinan di rumah. Seperti disiplin dalam menjalankan shalat, menjaga lingkungan.

\section{3) Strategi Pembelajaran Kooperatif Tipe TGT (Teams Games Tournament)}

Pembelajaran kooperatif adalah pendekatan pembelajaran yang berfokus pada penggunaan kelompok kecil siswa untuk bekerja sama dalam memaksimalkan kondisi belajar untuk mencapai tujuan belajar. ${ }^{4}$ Pembelajaran kooperatif muncul dari konsep bahwa peserta didik akan lebih mudah menemukan dan memahami konsep yang sulit jika mereka saling berdiskusi dengan temannya. Dengan kata lain, dalam menyelesaikan tugas kelompoknya, setiap peserta didik anggota kelompok harus saling bekerja sama dan saling membantu satu sama lain.

Kegiatan belajar bersama dapat membantu memacu belajar aktif. Dengan berkelompok peserta didik dapat berdiskusi dan mengajarkan kepada

${ }^{4}$ Sugiyanto, Model-model Pembelajaran Inovatif, (Surakarta: Yuma Pustaka, 2010), hlm.37. 
PIWULANG: Jurnal Pendidikan Agama Islam, Vol. 3 No. 2 Maret 2021, 143-156

P-ISSN : 2622-5638. E-ISSN : 2622-5654

Homepage: http://e-journal.staima-alhikam.ac.id/index.php/piwulang

teman-temannya. Hal ini memungkinkan peserta didik memperoleh pemahaman dan penguasaan materi pelajaran. ${ }^{5}$ Seperti yang dikutip Agus Suprijono, kontruktivis sosial Vygotsky menekankan bahwa peserta didik mengkontruksi pengetahuan melalui interaksi sosial dengan orang lain. Keterlibatan dengan orang lain membuka kesempatan bagi mereka mengevaluasi dan memperbaiki pemahaman. ${ }^{6}$

TGT merupakan salah satu jenis pembelajaran kooperatif. TGT pada mulanya dikembangkan oleh David De Vries dan Keith Edwards, ini merupakan metode pembelajaran pertama dari Johns Hopkins. Strategi ini menggunakan pelajaran yang sama yang disampaikan guru dan tim kerja yang sama seperti dalam STAD, tetapi menggantikan kuis dengan turnamen mingguan, dimana siswa memainkan game akademik dengan anggota tim lain untuk menyumbangkan poin bagi skor timnya. ${ }^{7}$ Hanya saja, untuk menambah skor perolehan tim/kelompok setelah pelaksanaan kuis, antar-kelompok dipertandingkan suatu permainan edukatif (educative games). Jadi, guru harus mempersiapkan suatu permainan matematis yang bersifat mendidik yang dimainkan siswa setelah pelaksanaan kuis. Dengan demikian, kelompok siswa melakukan lomba bermain dengan kelompok lain untuk memperoleh tambahan skor/ poin bagi tim mereka. Pembelajaran kooperatif disusun dalam sebuah usaha untuk meningkatkan partisipasi peserta didik, memfasilitasi peserta didik dengan pengalaman sikap kepemimpinan dan membuat keputusan dalam kelompok, serta memberikan kesempatan kepada peserta didik untuk berinteraksi dan belajar bersama-sama yang berbeda latar belakangnya. Pembelajaran kooperatif menjadi sangat efektif jika materi pembelajaran tersedia lengkap di kelas, ruang guru, perpustakaan, ataupun dipusat media. Apabila diperhatikan secara seksama, maka pembelajaran kooperatif ini mempunyai ciri-ciri tertentu dibandingkan dengan model lainnya yaitu sebagai berikut:

a. Peserta didik bekerja dalam kelompok secara kooperatif untuk menuntaskan materi belajar.

b. Kelompok dibentuk dari peserta didik yang mempunyai

\footnotetext{
${ }^{5}$ Melvin L. Silberman, Active Learning 101 cara belajar siswa aktif, terj. Lita, (Bandung: Penerbit Nusamedia kerjasama penerbit Nuansa, 2004), Cet. I, hlm. 31

${ }^{6}$ Agus Suprijono, Cooperative Learning, Teori dan Aplikasi PAIKEM, (Yogyakarta: Pustaka Pelajar, 2009), Cet I, hlm.55

7 Robert E. Slavin, Cooperative Learning Teori, Riset dan Praktik, Diterjemahkan dari cooperative learning theory, research and practice (London : Alymand Bacon : 2005) penerjemah Nurulita Nasution, (Bandung: Nusa Media, 2008), cet-1, hlm. 13.
} 
PIWULANG: Jurnal Pendidikan Agama Islam, Vol. 3 No. 2 Maret 2021, 143-156

P-ISSN : 2622-5638. E-ISSN : 2622-5654

Homepage: http://e-journal.staima-alhikam.ac.id/index.php/piwulang

kemampuan tinggi, sedang, dan rendah.

c. Bila memungkinkan, anggota kelompok berasal dari ras, budaya, suku, jenis kelamin yang beragam.

d. Penghargaan lebih berorientasi kepada kelompok dari pada individu

Dalam uraian tinjauan tentang pembelajaran kooperatif ini, dapat disimpulkan bahwa pembelajaran kooperatif tersebut memerlukan kerjasama antar peserta didik dan saling ketergantungan dalam struktur dalam pencapaian tugas, tujuan, dan penghargaan. Keberhasilan kelompok ini tergantung dari keberhasilan masing-masing individu dalam kelompok, di mana keberhasilan tersebut sangat berarti untuk mencapai suatu tujuan yang positif dalam belajar kelompok. Strategi pembelajaran kooperatif tipe TGT menggunakan turnamen akademik, dan menggunakan kuis-kuis dan sistem skor kemajuan individu dimana para peserta didik berlomba sebagai wakil tim mereka dengan anggota lain yang bekerja. Aktivitas belajar dengan permainan yang dirancang dalam pembelajaran kooperatif model TGT memungkinkan peserta didik dapat belajar lebih rileks disamping menumbuhkan tanggung jawab, kerjasama, persaingan sehat dan keterlibatan belajar. Setidaknya terdapat lima komponen utama dalam TGT yaitu:

1. Penyajian Kelas

Pada awal pembelajaran pendidik menyampaikan materi dalam penyajian kelas, biasanya dilakukan dengan pengajaran langsung atau dengan ceramah, diskusi yang dipimpin pendidik. Pada saat penyajian kelas ini peserta didik harus benar-benar memperhatikan dan memahami materi yang disampaikan pendidik, karena akan membantu peserta didik bekerja lebih baik pada saat kerja kelompok dan pada saat game karena skor game akan menentukan skor kelompok.

2. Kelompok (Teams)

Kelompok biasanya terdiri dari 5 sampai 7 peserta didik yang anggotanya heterogen dilihat dari prestasi akademik, jenis kelamin, dan ras atau etnik. Fungsi kelompok adalah untuk lebih mendalami materi bersama teman kelompoknya dan lebih khusus untuk mempersiapkan anggota kelompok agar bekerja dengan baik dan optimal pada saat game.

3. Permainan (Game)

Game terdiri dari pertanyaan-pertanyaan yang dirancang untuk menguji pengetahuan yang didapat peserta didik dari penyajian kelas dan belajar kelompok. Kebanyakan game terdiri dari 
PIWULANG: Jurnal Pendidikan Agama Islam, Vol. 3 No. 2 Maret 2021, 143-156

P-ISSN : 2622-5638. E-ISSN : 2622-5654

Homepage: http://e-journal.staima-alhikam.ac.id/index.php/piwulang

pertanyaan-pertanyaan sederhana bernomor. Peserta didik memilih kartu bernomor dan mencoba menjawab pertanyaan yang sesuai dengan nomor itu. Siswa yang menjawab benar akan mendapatkan skor. Skor ini yang nantinya dikumpulkan untuk menentukan team mana yang mendapat skor tertinggi dan akan diberi penghargaan sebagai pemenang dari game ini.

4. Tournament

Tournament adalah sebuah struktur dimana game berlangsung. Biasanya berlangsung pada akhir minggu atau pada setiap unit setelah guru memberikan presentasi di kelas dan tim telah melaksanakan kerja kelompok terhadap lembar kegiatan. Bagi team yang telah menyelesaikan soal-soal game terlebih dahulu, diminta untuk mempresentasikan hasilnya dengan diwakili oleh masing-masing anggota regunya yang menjawab. Kompetisi yang seimbang ini, memungkinkan para peserta didik dari semua tingkatan kinerja sebelumnya berkontribusi secara maksimal terhadap skor tim mereka, jika mereka melakukan yang terbaik.

5. Penghargaan kelompok (Teams Recognize)

Guru kemudian mengumumkan kelompok yang menang, masingmasing tim akan mendapat sertifikat atau hadiah apabila rata-rata skor memenuhi kriteria yang ditentukan. Suatu kelompok akan mendapat julukan "Super Teams" jika rata-rata skor 45 atau lebih, "Great Teams" apabila rata-rata mencapai 40-45 dan "Good Teams" apabila rata-ratanya 30-40.

Implementasi strategi TGT ini secara teknis Slavin mengemukakan empat langkah utama dalam pembelajaran dengan teknik TGT yang merupakan siklus regular dari aktivitas pembelajaran, sebagai berikut:

a) Step 1: Pengajaran, pada tahap ini guru menyampaikan materi pelajaran.

b) Step 2: Belajar Tim, para siswa mengerjakan lembar kegiatan dalam tim mereka untuk menguasai materi.

c) Step 3: Turnamen, para siswa memainkan game akademik dalam kemampuan yang homogen, dengan meja turnamen tiga peserta (kompetisi dengan tiga peserta).

d) Step 4: Rekognisi Tim, yaitu dengan menghitung skor tim berdasarkan skor turnamen anggota tim, dan tim tersebut akan direkognisi apabila mereka berhasil melampaui kriteria yang telah ditetapkan sebelumnya. 
PIWULANG: Jurnal Pendidikan Agama Islam, Vol. 3 No. 2 Maret 2021, 143-156

P-ISSN : 2622-5638. E-ISSN : 2622-5654

Homepage: http://e-journal.staima-alhikam.ac.id/index.php/piwulang

\section{4) Mata Pelajaran Fiqih}

Mata pelajaran fiqih adalah mata pelajaran pendidikan agama Islam di Madrasah Tsanawiyah (MTs) yang diarahkan untuk menyiapkan peserta didik untuk mengetahui, memahami, melaksanakan dan mengamalkan ketentuan hukum Islam dengan benar. Pengalaman tersebut diharapkan dapat menumbuhkan ketaatan menjalankan hukum Islam, disiplin dan tanggung jawab sosial yang tinggi dalam kehidupan pribadi maupun sosialnya (way of life). Dalam pelajaran fiqih peserta didik dikenakan pada konsepsi perilaku islami baik secara individu maupun secara sosial. Kaidah fiqih bersumber dari al-Quran dan as-sunnah yang di dalamnya terkandung berbagai cara beribadah, berperilaku dan bermasyarakat sesuai dengan cara yang diridhai Allah SWT.

Hasil belajar fiqih adalah suatu pengetahuan dan keterampilan yang dimiliki peserta didik dalam mata pelajaran fiqih setelah melalui proses dan aktifitas belajar mengajar dilanjutkan dengan nilai tes atau angka yang diperoleh dari hasil tes. Dari karakteristik pelajaran fiqih, guru perlu mengembangkannya lebih lanjut sesuai dengan ramburambu pelajaran fiqih, sehingga implementasi kurikulum fiqih sesuai dengan kebutuhan dan kondisi peserta didik.

\section{E. Kesimpulan}

Berdasarkan hasil observasi awal dan wawancara peneliti dengan Guru MTs Negeri Putussibau, bahwa dalam proses pembelajaran fiqih strategi yang digunakan adalah lebih banyak menggunakan metode konvensional yaitu ceramah. Peserta didik hanya menelan dan mendengarkan hal-hal yang disampaikan oleh guru. Apalagi karakteristik anak didik khususnya kelas yang penulis teliti yaitu kelas VIII, kurang tertarik belajar fiqih.

Strategi yang digunakan jelas kurang tepat jika diterapkan dalam proses KBM tersebut. Akibatnya, hasil belajar peserta didik belum maksimal. Untuk mengatasi permasalahan tersebut peneliti menggunakan strategi pembelajaran kooperatif tipe Teams Games Tournament (TGT). Setelah peneliti menggunakan strategi pembelajaran TGT, diperoleh hasil perhitungan $t$-test yaitu thitung $=2,811$. Dengan $\mathrm{dk}=34+34-2=66$ dan taraf nya ta $5 \%$, diperoleh $t_{\text {tabel }}=1,67$. Karena thitung $>t_{\text {tabel }}$ maka signifikan dan hipotesis yang diujikan dapat diterima. Dengan demikian, maka hasilnya dapat dikemukakan bahwa adanya perbedaan hasil belajar antara peserta didik yang diajarkan dengan strategi pembelajaran kooperatif tipe TGT pada mata pelajaran fiqih dengan peserta didik yang diajarkan dengan model pembelajaran konvensional. Dari kesimpulan diatas dapat 
PIWULANG: Jurnal Pendidikan Agama Islam, Vol. 3 No. 2 Maret 2021, 143-156

P-ISSN : 2622-5638. E-ISSN : 2622-5654

Homepage: http://e-journal.staima-alhikam.ac.id/index.php/piwulang

dikatakan bahwa adanya variasi dalam proses pembelajaran dengan menggunakan strategi pembelajaran kooperatif tipe TGT berpengaruh efektif dalam meningkatkan hasil belajar fiqih di MTs Negeri Putussibau.

\section{Daftar Pustaka}

Makmun, Abin Syamudin, Psikologi Kependidikan, Bandung: PT Remaja Rosdakarya, 2002.

Mulyasa, E., Kurikulum Tingkat Satuan Pendidikan Sebuah Panduan Praktis, Bandung: Remaja Rosdakarya, 2007.

Silberman, Melvin L., Active Learning 101 cara belajar siswa aktif, terj. Lita, Bandung: Penerbit Nusamedia kerjasama penerbit Nuansa, 2004.

Slavin, Robert E., Cooperative Learning Teori, Riset dan Praktik, Diterjemahkan dari cooperative learning theory, research and practice London : Alymand Bacon : 2005 penerjemah Nurulita Nasution, Bandung: Nusa Media, 2008, cet-1.

Sudijono, Anas, Pengantar Evaluasi Pendidikan Jakarta: PT Raja Grafindo Persada, 2006.

Sugiono, Statistika untuk Penelitian, Bandung: CV. Alfabeta, 2005, cet. 8.

Sugiyanto, Model-model Pembelajaran Inovatif, Surakarta: Yuma Pustaka, 2010

Suprijono, Agus, Cooperative Learning, Teori dan Aplikasi PAIKEM, Yogyakarta: Pustaka Pelajar, 2009, Cet I.

Winarsunu, Tulus, Statistik Dalam Penelitian Psikologi dan Pendidikan, Malang: UMM Press,2007, Cet.4. 